\title{
13. PALEOMAGNETIC RESULTS FOR THE INDIAN AND ARABIAN PLATES FROM ARABIAN SEA CORES
}

\author{
R. B. Whitmarsh, National Institute of Oceanography, Wormley, Godalming, Surrey, United Kingdom \\ N. Hamilton and R. B. Kidd, Southampton University, Southampton, England
}

\section{INTRODUCTION}

The study of Vine-Matthews magnetic anomalies in the oceans has reached the stage where quite detailed analyses of sea-floor spreading episodes during Cenozoic time can be worked out. These results, when combined with techniques for determining the directions of motion between plates, give a fairly complete description of the past relative motion between plates. Paleomagnetic measurements, on the other hand, define the motion of a plate with respect to the earth's axis of rotation, assuming that the geomagnetic field when averaged over tens of thousands of years can be represented by an axial dipole. The motions deduced from sea-floor spreading and paleomagnetism are not in general the same, since different frames of reference are used, and the two sorts of measurements are complementary.

\section{OBJECTIVES}

The sea-floor spreading history of the Indian Ocean during the Cenozoic has been worked out from magnetic anomalies by McKenzie and Sclater (1971) and has been elaborated by Whitmarsh (Chapter 14). There are few paleomagnetic results, however, from Cenozoic rocks of the adjacent continents, especially from India. McElhinny (1968) and Wellman and McElhinny (1970) showed from a study of the Deccan traps that India had moved northward through 50 degrees of latitude in the last 65 m.y., but no paleomagnetic observations were known which indicated the motion of India within this time interval. It was not certain that the rate of northward movement had been constant; Wellman et al. (1969) had discovered a sharp bend in the apparent polar wander curve of Australia 25 to 34 m.y. ago, indicating that a change in the direction of motion of the Indo-Australian plate occurred at this time. Thus, the plans for Leg 23, which called for Glomar Challenger drilling some half dozen holes in the Arabian Sea, offered a unique chance to sample Cenozoic sediments and basalts for paleomagnetic measurements. Not only was it hoped to obtain detailed information about the northward drift of India, but also to compare results from sites situated on both sides of the Owen Fracture Zone so as to gauge the Cenozoic history of transverse motion along this fault.

\section{SAMPLING AND MEASURING}

It is unfortunate that at present azimuthally oriented cores cannot be obtained onboard Glomar Challenger. Thus, the only available reference direction is in the axis of the hole and so magnetic inclination is the prime parameter to be measured. During Leg 23 in the Arabian Sea there was no means of measuring the inclination of the holes, although this has been done occasionally on subsequent legs. Seven measurements made during Leg 25 indicate that the hole was never off vertical by more than $5^{\circ}$ (R. Schlich, personal communication). Some sediments may give low magnetic inclination angles due to compaction; however the results of Opdyke and Henry (1969) demonstrated that this is not so for deep-sea cores recovered from the top 10 meters of sediment. They found that the magnetic inclinations of cores from a wide range of latitude and longitude fitted the hypothesis of a geocentric axial dipole within experimental error. The Glomar Challenger cores were retrieved from subbottom depths up to two orders of magnitude greater. However, bulk density measurements on many Deep Sea Drilling Project cores indicate that density increases systematically with depth only slightly, if at all. Any compaction effect on inclination therefore is probably slight. It is convenient to choose paleomagnetic samples which represent at least $10^{3}$ years so as to average out the secular variations of the geomagnetic field. The $2.5-\mathrm{cm}-\mathrm{long}$ sediment samples obtained in the Arabian Sea were taken from sediments in which the mean sedimentation rate lay between 5 and $190 \mathrm{~m} / \mathrm{m} . \mathrm{y}$. and thus represented between 5000 and 134 years. An extreme rate of at least 600 $\mathrm{m} / \mathrm{m} . \mathrm{y}$. was met at Site 222, and samples from this site will represent up to 42 years. Several samples of igneous basement were also obtained.

The sampling and measuring procedures adopted for this study are described in Chapter 2 . All the results considered below were obtained from sediment samples which had been "cleaned" in a 50 -oersted alternating field or from basalts which had been "cleaned" in a 100-oersted field. The results are discussed in detail in the appropriate site chapters.

\section{NORTHWARD DRIFT OF THE INDIAN PLATE}

The sites from which paleomagnetic samples were obtained are shown in Figure 1. Since it is known that India's paleolatitude changed by $50^{\circ}$ during the Cenozoic, it can be assumed that inclination measurements will describe this large motion to a first approximation. Because only completely undisturbed sediments were sampled, no one site in the Arabian Sea yielded samples covering the whole of the penetrated section. Thus, to consider the time interval represented by this section, the inclination results from the six sites, scattered over $10^{\circ}$ of latitude and $13^{\circ}$ of longitude, must be combined. This has been done by converting inclinations to paleolatitudes (Table 1) and by reducing these paleolatitudes to one site (Site 219) by subtracting or adding the present latitude difference

\footnotetext{
${ }^{1}$ Present address: National Institute of Oceanography, Wormley, Godalming, Surrey, United Kingdom.
} 


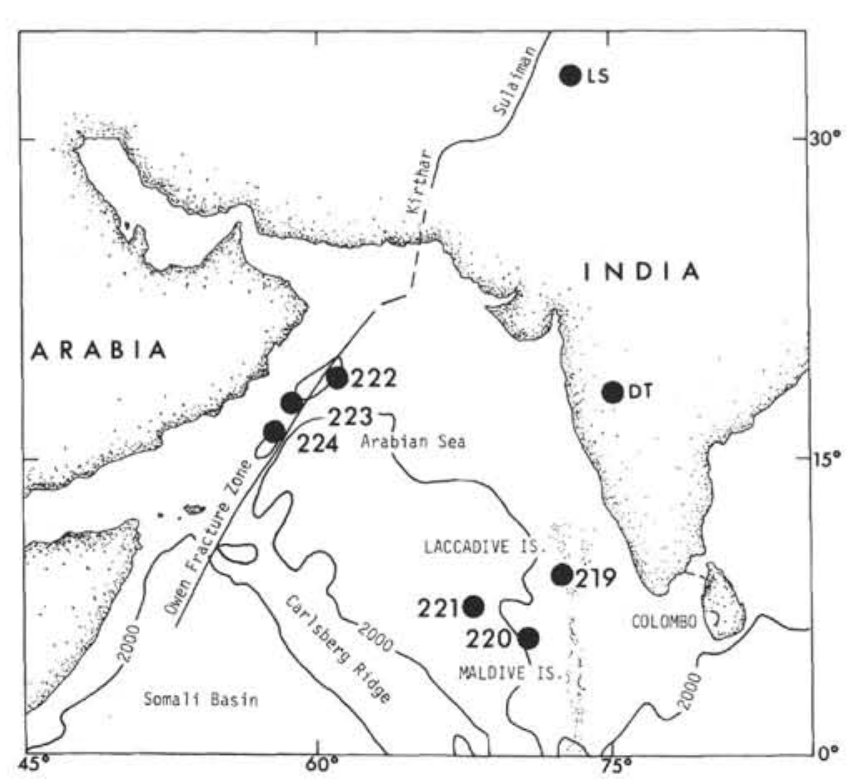

Figure 1. Sketch map showing position of sites drilled during Leg 23 together with the position of the Owen Fracture Zone and its continuation in West Pakistan as the Kirthar-Sulaiman Shear Zone. LS = Lower Siwalik site, $D T=$ Deccan trap sites (mean position). See text for discussion of data from these sites.

between each site and the reference site (Figure 2). There is some ambiguity in this procedure since it is not possible to tell whether the sites were originally north or south of the equator. The choice of hemisphere has been made so that the data are consistent with the two published Indian paleomagnetic poles. The above method of combining the data assumes that lines of paleolatitude (paleoparallels) have remained east-west. This can be tested by comparing latitudinal differences between sites. This test can only be made if paleomagnetic data are available for the same time period at two or more sites. With the present data three pairs of measurements are available which satisfy this condition (Table 2). Statistically there appears to be no significant difference between past and present latitudinal differences for the three pairs of sites, and thus our data show that paleoparallels do not remain east-west. A better test is to see whether observed paleomagnetic poles lie on the same meridian as sampling sites (i.e., the longitude differences between them should be $0^{\circ}$ or $180^{\circ}$ ). There are two sets of such poles now available for India (Table 3), and these results suggest that paleoparallels have remained east-west for the last 14 m.y., but that they suffered a slight net rotation (about $25^{\circ}$ ) between 65 and 14 m.y. From the above arguments, therefore, the technique of combining data used in Figure 2 appears to be valid, at least as a first approximation.

The results presented in Figure 2 show that there was a northward drift of the Indian plate at a mean rate of 26 $\mathrm{cm} / \mathrm{yr}$ from the end of the Cretaceous until at least Middle Eocene times, followed by a slower mean rate of drift of $16 \mathrm{~cm} / \mathrm{yr}$ beginning in the Miocene. This two-phase history of movement is in accord with that tentatively suggested by Wensink (1973), and the Cretaceous-Eocene rate agrees quite well with his estimate of $30 \mathrm{~cm} / \mathrm{yr}$ deduced from changes in magnetic inclination within the Deccan traps sequence. It is perhaps surprising to note the relatively rapid northward drift of India in the last 20 m.y., especially when it is seen that Canberra (also on the Indian plate during this period) has moved northward only about $4^{\circ}$ in the same period at a mean rate of $2.2 \mathrm{~cm} / \mathrm{yr}$ (Wellman et al., 1969). Figure 2 also suggests that the Indian plate may even have moved slightly southward between 44 and 24 m.y. ago. It is interesting that this period of probable minimum latitude change includes the time when sea-floor spreading was least active in the western Indian Ocean (McKenzie and Sclater, 1971; Whitmarsh, this volume).

The pre-Middle Miocene data from Sites 223 and 224 do not fit the two linear trends of rapid northward movement. This was anticipated and is believed to indicate that the Owen Fracture Zone was a transform fault throughout the early Cenozoic and decoupled these sites (and ArabiaSomalia) from the Indian plate. The Upper/Middle Miocene result of Site 223 is consistent with the $16 \mathrm{~cm} / \mathrm{yr}$ trend and suggests that for about the last 10 m.y. Arabia and India have been moving northward at essentially the same rate, i.e., that there has been no large movement across the Owen Fracture Zone during this period. The trend of the observations from Sites 223 and 224 intersects the $16 \mathrm{~cm} / \mathrm{yr}$ line at around $10 \mathrm{~m} . \mathrm{y}$., and this could be construed to mean that the Owen Fracture Zone was active up to this time. It follows, therefore, that during the first half of the Gulf of Aden's spreading history (20 to 10 m.y. ago) sea-floor spreading was proceeding much more rapidly to the east of the Owen Fracture Zone than to the west. However, the data are limited and these conclusions are tentative.

The results from Sites 223 and 224 were reduced to one site (Site 223) by the method described above and have been plotted in Figure 3. It is well known that Arabia has rotated about $7^{\circ}$ in the last 10 m.y. during the opening of the Gulf of Aden and the Red Sea (Irving and Tarling, 1961; Tarling et al., 1967) and this must be borne in mind when interpreting Figure 3. However, Sites 223 and 224 are so close $\left(2.3^{\circ}\right.$ apart $)$ that their results can probably be combined with a small resulting error. The apparent near constancy of latitude between the Paleocene and the Miocene, if real, is in contrast to the $25^{\circ}$ net northward movement of Africa which occurred between 110 m.y. and about 30 m.y. ago. The details of this movement are not known however (McElhinny, 1973), and it is possible that there has been almost no change in the latitude of Africa for the last $60 \mathrm{~m} . \mathrm{y}$. It is certain, however, that the latitude of Site 223 has changed in the last 10 m.y. due, at least in part, to the opening of the Gulf of Aden, but this is not detectable in our data.

\section{SUMMARY}

1) In spite of the difficulties in interpreting paleomagnetic data from Glomar Challenger cores, it is shown that to a first approximation the northward drift of the Indian plate during Cenozoic time can be determined by such observations.

2) It is estimated that the Indian plate moved northward at mean rates of 26 and $16 \mathrm{~cm} / \mathrm{yr}$ for the periods 
TABLE 1

Mean Paleolatitudes for Leg 23 Sites Reduced to One Site (Site 219)

\begin{tabular}{|c|c|c|c|c|c|c|c|}
\hline Site & $\begin{array}{l}\text { Present } \\
\text { Latitude } \\
\end{array}$ & $\begin{array}{l}\text { Age } \\
\text { (m.y.) }\end{array}$ & $\begin{array}{c}\begin{array}{c}\text { Number } \\
\text { of } \\
\text { Observations }\end{array} \\
\end{array}$ & $\begin{array}{c}\text { Observed } \\
\text { Paleolatitude }\end{array}$ & $\begin{array}{l}\text { Latitude } \\
(\mathrm{N} \text { or } \mathrm{S})\end{array}$ & $\begin{array}{c}\text { Reduced } \\
\text { Paleolatitude } \\
\end{array}$ & $\begin{array}{r}\text { Latitude } \\
(\mathrm{N} \text { or } \mathrm{S})\end{array}$ \\
\hline \multicolumn{8}{|l|}{ Sediments } \\
\hline 219 & 9.0 & $\begin{array}{l}\text { U. Paleocene } \\
(54-59)\end{array}$ & 11 & $15.5 \pm 2.8$ & $\mathrm{~S}$ & $15.5 \pm 2.8$ & $\mathrm{~S}$ \\
\hline 220 & 6.5 & $\begin{array}{l}\text { L.-M. Eocene } \\
(45-54)\end{array}$ & 14 & $11.4 \pm 1.4$ & $S$ & $8.9 \pm 1.4$ & $\mathrm{~S}$ \\
\hline \multirow[t]{2}{*}{221} & 8.0 & $\begin{array}{l}\text { Pleistocene } \\
(0-2)\end{array}$ & 5 & $7.7 \pm 3.0$ & $\mathrm{~N}$ & $8.7 \pm 3.0$ & $\mathrm{~N}$ \\
\hline & & $\begin{array}{l}\text { Pliocene/Miocene }{ }^{\mathrm{a}} \\
(5-22.5)\end{array}$ & 6 & $11.7 \pm 3.0$ & S & $10.7 \pm 3.0$ & $\mathrm{~S}$ \\
\hline \multirow[t]{2}{*}{222} & 20.1 & $\begin{array}{l}\text { L. Pliocene } \\
(3-5)\end{array}$ & 10 & $11.5 \pm 2.5$ & $\mathrm{~N}$ & $0.4 \pm 2.5$ & $\mathrm{~N}$ \\
\hline & & $\begin{array}{l}\text { U. Miocene } \\
(5-6)\end{array}$ & 78 & $9.7 \pm 0.8$ & $\mathrm{~N}$ & $1.4 \pm 0.8$ & $\mathrm{~S}$ \\
\hline \multirow[t]{2}{*}{223} & 18.8 & $\begin{array}{l}\text { U.-M. Miocene } \\
(5-14)\end{array}$ & 3 & $8.1 \pm 1.8$ & $\mathrm{~N}$ & $1.7 \pm 1.8$ & $\mathrm{~S}$ \\
\hline & & $\begin{array}{l}\text { L. Miocene } \\
(14-22.5)\end{array}$ & 3 & $2.9 \pm 0.4$ & $\mathrm{~N}$ & $4.6 \pm 0.4$ & $\mathrm{~S}$ \\
\hline 224 & 16.5 & $\begin{array}{l}\text { U.-M. Oligocene } \\
(22.5-34)\end{array}$ & 15 & $5.3 \pm 0.8$ & $\mathrm{~N}$ & $2.2 \pm 0.8$ & $\mathrm{~S}$ \\
\hline L. Siwaliks ${ }^{\mathrm{b}}$ & 32.8 & $\begin{array}{l}\text { M. Miocene } \\
(10.5-14)\end{array}$ & 40 & 15.0 & $\mathrm{~N}$ & 8.8 & $\mathrm{~S}$ \\
\hline \multicolumn{8}{|l|}{ Basalts } \\
\hline 220 & 6.5 & $\begin{array}{l}\text { L. Eocene } \\
(49-54)\end{array}$ & 17 & $6.1 \pm 0.7$ & S & $3.6 \pm 0.7$ & $\mathrm{~S}$ \\
\hline 221 & 8.0 & $\begin{array}{l}\text { M. Eocene } \\
(45-49)\end{array}$ & 6 & $8.3 \pm 3.3$ & $\mathrm{~S}$ & $7.3 \pm 3.3$ & $\mathrm{~S}$ \\
\hline 223 & 18.8 & $\begin{array}{l}\text { U. Paleocene } \\
(54-47)\end{array}$ & 7 & $9.5 \pm 2.7^{c}$ & $\mathrm{~N}$ & $0.3 \pm 2.7$ & $\mathrm{~S}$ \\
\hline Deccan traps $s^{\mathrm{d}}$ & 18.0 & $(65)$ & ca. 1000 & 31.7 & $\mathrm{~S}$ & 40.7 & $\mathrm{~S}$ \\
\hline
\end{tabular}

Note: Data were only included in this table if there were at least 3 measurements for one geological period. The hemisphere for the observed paleolatitude was assumed, to fit two observed poles for India. All errors are standard errors of the mean.

${ }^{\text {a }}$ Probably only one Pliocene observation; unfossiliferous cores.

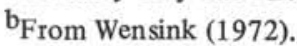

${ }^{c}$ Omitting extreme inclination of $48^{\circ}$ from a volcanogenic breccia.

${ }^{d}$ From McElhinny (1968) and Wellman and McElhinny (1970).

Paleocene to Middle Eocene and Miocene to Recent, respectively. There may have been no movement or even a reversal in direction in the intervening period.

3) Data from a site west of the Owen Fracture Zone are consistent with there having been no large transverse movement across this fault in the last $10 \mathrm{~m} . \mathrm{y}$.

4) The sites from west of the Owen Fracture Zone suggest that Arabia did not change latitude in the interval 65 to 10 m.y. ago by more than $5^{\circ}$.

\section{ACKNOWLEDGMENTS}

We are grateful to D. H. Tarling and R. W. Girdler for suggesting improvements to the manuscript.

\section{REFERENCES}

Irving, E. and Tarling, D. H., 1961. The paleomagnetism of the Aden volcanics: J. Geophys. Res., v. 66, p. 549-556.

McElhinny, M. W., 1968. Northward drift of Indiaexamination of recent paleomagnetic results: Nature, v. 217, p. $342-344$.

1973. Paleomagnetism and plate tectonics: Cambridge (Cambridge Univ. Press).

McKenzie, D. P. and Sclater, J. G., 1971. The evolution of the Indian Ocean since the Late Cretaceous: Geophys. J.R.A.S., v. 25, p. 437-528.

Opdyke, N. D. and Henry, K. W., 1969. A test of the dipole hypothesis. Earth Planet. Sci. Lett., v. 6, p. 139-151.

Tarling, D. H., Sanver, N., and Hutchings, A. M. J., 1967. Further paleomagnetic results from the Federation of South Arabia: Earth Planet. Sci. Lett., v. 3, p. 148-154. 


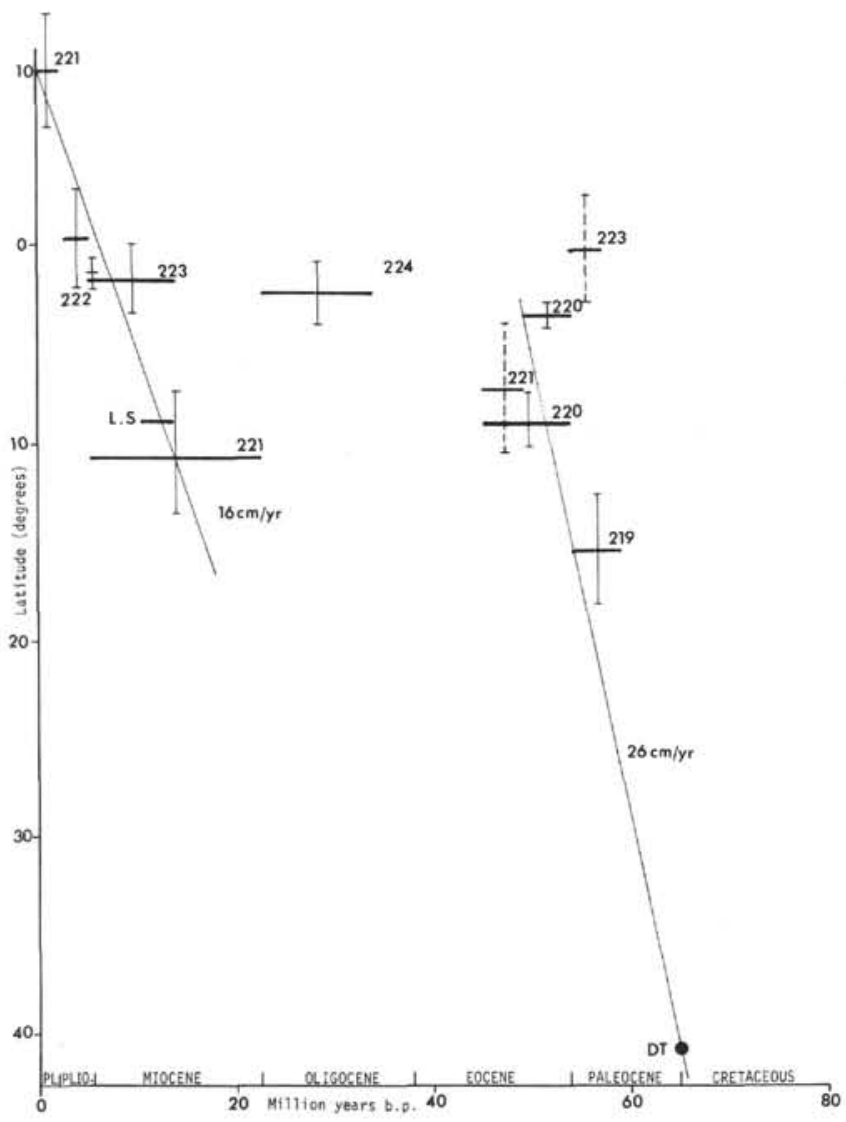

Figure 2. Plot of paleolatitudes from all sites reduced to a common site (Site 219). Thick bars denote the age range of the observations; vertical error bars are 2 standard errors long; dashed bars denote basalt data; solid bars denote sediment data. $L S=$ paleolatitude of Lower Siwaliks, $D T=$ paleolatitude of Deccan traps. The two trend lines were fitted by eye with the constraint that they should pass through the points (0.m.y., $\left.9^{\circ} \mathrm{N}\right)$ and 65 m.y., $\left.40.7^{\circ} \mathrm{S}\right)$, respectively.

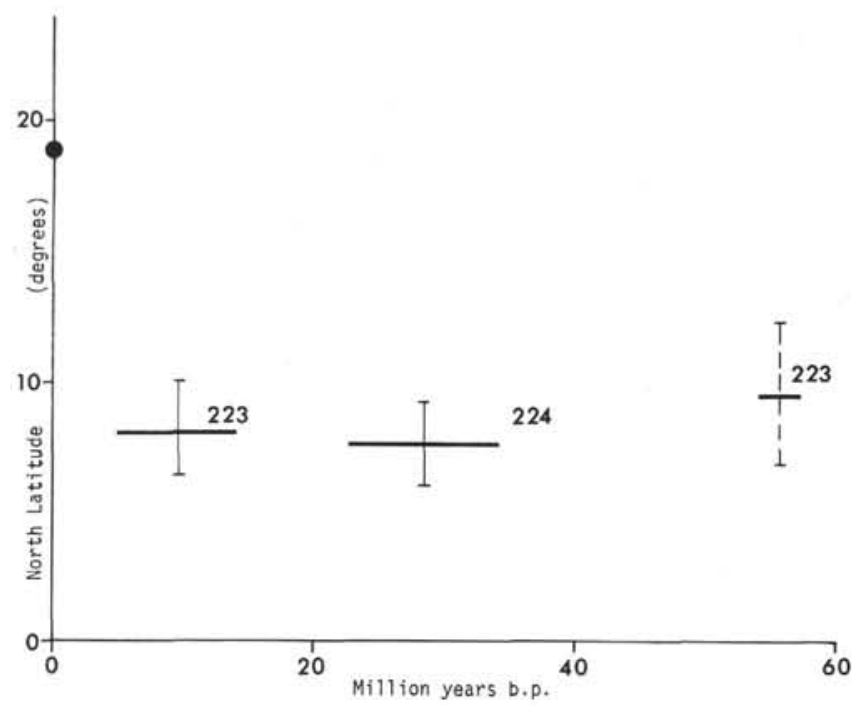

Figure 3. Plot of paleolatitudes of sites situated west of the Owen Fracture Zone reduced to a common site (Site 223). See Figure 2 caption for description of figure. denotes present latitude of Site 223.

Wellman, P. and McElhinny, M. W., 1970. K-Ar ages of the Deccan traps, India: Nature, v. 227, p. 595-596.

Wellman, P., McElhinny, M. W., and McDougall, I., 1969. On the polarwander path for Australia during the Cenozoic: Geophys. J. R.A.S., v. 18, p. 371-395.

Wensink, H., 1972. A note on the paleomagnetism of the Lower Siwaliks near Choa Saiden Shah, Potwar Plateau, West Pakistan: Pakistan J. Sci. Ind. Res., v. 15, p. 89-91. 1973. Newer paleomagnetic results of the Deccan traps, India: Tectonophysics, v. 17, p. 41-59. 
TABLE 2

Paleomagnetic Data

\begin{tabular}{|c|c|c|c|c|c|c|}
\hline \multirow[b]{2}{*}{ Site } & \multirow[b]{2}{*}{ Age } & \multicolumn{2}{|c|}{ Present } & \multicolumn{2}{|c|}{ Past } & \multirow[b]{2}{*}{$t^{\mathrm{b}}$} \\
\hline & & Latitude & Diff. & Latitude $^{\mathrm{a}}$ & Difference & \\
\hline \multicolumn{7}{|c|}{ Sediments } \\
\hline $\begin{array}{l}219 \\
220\end{array}$ & $\begin{array}{l}\text { U. Paleocene } \\
\text { L. Eocene }\end{array}$ & $\begin{array}{l}9.0 \mathrm{~N} \\
6.5 \mathrm{~N}\end{array}$ & $2: 5$ & $\begin{array}{l}15.5 \pm 2.8 \mathrm{~S} \\
10.0 \pm 1.3 \mathrm{~S}\end{array}$ & $-5.5 \pm 3.1$ & 2.6 \\
\hline 221 & $\begin{array}{l}\text { Miocene/Pliocene } \\
\text { U. Miocene }\end{array}$ & $\begin{array}{r}8.0 \mathrm{~N} \\
20.1 \mathrm{~N}\end{array}$ & 12.1 & $\begin{aligned} 11.7 & \pm 3.0 \mathrm{~S} \\
8.8 & \pm 0.8 \mathrm{~N}\end{aligned}$ & $20.5 \pm 3.1$ & 2.7 \\
\hline \multicolumn{7}{|l|}{ Basalts } \\
\hline $\begin{array}{l}220 \\
221\end{array}$ & $\begin{array}{l}\text { L. Eocene } \\
\text { M. Eocene }\end{array}$ & $\begin{array}{l}6.5 \mathrm{~N} \\
8.0 \mathrm{~N}\end{array}$ & 1.5 & $\begin{array}{l}6.1 \pm 0.7 \mathrm{~S} \\
8.3 \pm 3.3 \mathrm{~S}\end{array}$ & $-2.2 \pm 3.4$ & 1.1 \\
\hline
\end{tabular}

${ }^{\mathrm{a}} \mathrm{Hemisphere}$ of paleolatitude chosen for consistency with published poles in Figure 1.

b Student's $t$ parameter. All errors are standard errors of the mean.

TABLE 3

Cenozoic Indian Paleomagnetic Poles

\begin{tabular}{|c|c|c|c|c|}
\hline $\begin{array}{l}\text { Rock } \\
\text { Sequence }\end{array}$ & $\begin{array}{c}\text { Age } \\
\text { (m.y.) }\end{array}$ & Site & Pole & $\begin{array}{l}\text { Longitude } \\
\text { Difference }\end{array}$ \\
\hline $\begin{array}{l}\text { L. Deccan traps } s^{\mathrm{a}} \\
\text { U. Deccan traps }{ }^{\mathrm{a}} \\
\text { Deccan traps }\end{array}$ & 65 & $\begin{array}{l}18^{\circ} \mathrm{N}, 75^{\circ} \mathrm{E} \\
18^{\circ} \mathrm{N}, 75^{\circ} \mathrm{E} \\
22.7^{\circ} \mathrm{N}, 81.3^{\circ} \mathrm{E}\end{array}$ & $\begin{array}{l}30^{\circ} \mathrm{N}, 281^{\circ} \mathrm{E} \\
37^{\circ} \mathrm{N}, 282^{\circ} \mathrm{E} \\
33^{\circ} \mathrm{N}, 294^{\circ} \mathrm{E}\end{array}$ & $\begin{array}{l}206 \\
207 \\
213\end{array}$ \\
\hline L. Siwaliks b & $10.5-14$ & $32.8^{\circ} \mathrm{N}, 73.0^{\circ} \mathrm{E}$ & $72.1^{\circ} \mathrm{N}, 248.7^{\circ} \mathrm{E}$ & 172 \\
\hline
\end{tabular}

aFrom McElhinny (1973).

bFrom Wensink (1972) 